\title{
A descoberta do novo mundo na poética de Outra Lingua de Henryk Siewierski e na pintura histórica de Debret
}

Helciclever Barros da Silva Vitoriano ${ }^{1}$

RESUMO: O presente artigo objetiva analisar alguns poemas da obra Outra Lingua de Henryk Siewierski e alguns quadros de Jean-Baptiste Debret, membro da missão francesa no Brasil, sob o horizonte teórico da Semiótica peirceana.

ABSTRACT: This article aims to analyze some poems of the book by Henryk Other Language Siewierski and a few paintings of Jean-Baptiste Debret, a member of the French mission in Brazil, under the theoretical horizon of Peircean Semiotics.

PALAVRAS-CHAVE: Semiótica; Poesia; Pintura; Peirce.

KEYWORDS: Semiotics; Poetry; Painting; Peirce.

O presente artigo objetiva analisar sucintamente os poemas "Ítaca" (prólogo), "Canção do não-exílio", "O menino da praça", "Marajó", "Mãe d'água", "Serra da Barriga", da obra Outra Língua de Henryk Siewierski e os quadros "Casario" (figura 2), "Engenho Manual que Faz Caldo de Cana" (figura 3), "O Velho Orfeu Africano, Oricongo" (figura 4) e "Jovens Negras Indo à Igreja para Serem Batizadas" (figura 5), de Jean-Baptiste Debret, membro da missão artística francesa no Brasil, sob o horizonte teórico da Semiótica peirceana. Almeja-se evidenciar o trânsito primeiridade-terceiridade, sobretudo nos processos de iconização e metaforização propostos por (Oliveira, 1999), buscando apreender o percurso imagético de dois étrangers ao se depararem com a realidade brasileira dos séculos XIX (Debret) e XX-XXI (Siewierski).

1 Mestrando em Literatura e Práticas Sociais pela Universidade de Brasília - UnB, título da pesquisa: Cyrano de Bergerac: Teatro Romântico, Tradição Luciânica e Tonalidade do Risivel. Contato: helciclever@gmail.com 
Neste percurso é primordial revisitar conceitos básicos semiótica peirceana $^{i}$, abordagem que se traduz por uma versatilidade capaz de subsidiar interpretações das mais diversas linguagens artísticas; no nosso caso servirá de esteio à interpretação dos poemas e pinturas supramencionados.

A relação entre poesia e pintura é bastante antiga e ao mesmo tempo extremamente atual. Escritores como Horácio, que celebrizou, entre tantas outras, a frase "Uma pintura é um poema sem palavras", passando por Balzac em Obra-prima ignorada; Oscar Wilde em Retrato de Dorian Gray, chegando aos modernos Charles Baudelaire em O pintor da vida moderna; Guillaume Apollinaire em Caligramas; Murilo Mendes na série de poema Os murilogramas; Drummond em Estive em casa de Candinho, até os contemporâneos, Ohran Pamuk em Meu nome é vermelho e Alessandro Baricco em Oceano mar trabalharam, cada qual a seu modo, esta relação intima e bastante desafiadora entre literatura e pintura, especialmente entre poesia e pinturaii.

A nossa proposta analítica passa por um ângulo diverso da supracitada ligação poesia-pintura, pois o texto fonte deste trabalho, a obra Outra língua, de Siewierski não tematiza a pintura. O que se pretende é estabelecer vínculos relacionais entre esta obra com alguns quadros supracitados de Debret, tendo como foco a figuração que ambos, poeta e pintor, fizeram da realidade brasileira, levando em consideração seus diferentes matizes ideológicos e os diferentes momentos históricos de tal figuração. Assim, o que une os dois artistas em apreço, dentro dos fins aqui propostos, é a leitura artística que eles fazem do Brasil.

Como suporte teórico, recorremos a Oliveira (1999), que busca harmonizar e constatar sob a luz das concepções de Charles Sanders Peirce os elementos analiticos em comum entre poesia e pintura, tais como imagem, diagrama e metáfora, respectivamente primeiridade, secundidade e terceiridade, sendo que há subníveis em cada categoria, ou seja, há aspectos de primeiridade, secundidade e terceiridade tanto na imagem, quanto no diagrama e na metáfora. Aqui nosso propósito é 
adentrar da imagem à metáfora, do ícone ao símbolo na poética de Outra Língua e nos quadros supracitados de Debret, abstraindo no que for possivel o plano relacional e intermediário instaurado e plasmado na secundidade sígnica, sem perder de vista os aspectos culturais, históricos e políticos das obras estudadas.

\section{Mundos em contato}

Henryk Siewierski é polonês radicado no Brasil desde 1986. Antes de aportar em terras brasileiras fez incursões em Portugal onde travou contato com a poesia pessoana; é tradutor de Pessoa para o polonês e de poetas poloneses para a língua portuguesa. A cultura polaca ressoa no mundo lusófono, especialmente no Brasil, muito em função da indústria do professor titular de Literatura da Universidade de Brasília Siewierski, ao mesmo tempo em que o interesse pela cultura e literatura brasileiras vem crescendo na Polônia, por igual motivo.

Em seu livro Outra Língua, encontramos uma poética do "estranhamento", da apropriação do universo do outro, do senso de pertencimento à grande "aldeia" global. O poeta visita o novo mundo e se integra a ele, assim como revisita suas origens, redescobrindo sensações, visões, imagens marcantes que o reconciliam com a pátria mater que é afinal a Polônia, o Brasil e o mundo.

Fica a dúvida se a "outra língua" é a deixada no leste europeu que reacende em seu íntimo, ou será o português brasileiro com seus labirintos e horizontes? Talvez seja somente a lingua, o elemento universal que conecta todos os seres humanos, indistintamente no plano da comunicação e da interação possíveis.

Logo no prólogo da obra, o poeta nos traz "Ítacaiii", terra de retorno, imagem do reencontro com o solo nacional ao mesmo tempo em que nos remete a um lugar que se anseia muito estariv. Este poema prepara o leitor para visualizar as viagens do eu-lírico, para as idas e vindas de uma alma contemplativa e ansiosa por viver: 
Pedi e me foi oferecida

uma longa viagem a Ítaca

$(\ldots)$

Até que um dia

entramos numa baía,

gratos e felizes

como nunca,

baía de outros sonhos.

E agora não sei

se foi longe demais

ou se é este o fim

da viagem que pedi

O poeta se encontra em plena viagem, mas já não sabe os limites de sua investida. Tudo parece incerto, com exceção do desejo de mudança, da insaciabilidade onírica, típica das viagens em que o desconhecido e o perigo se encontram em cada paragem. O importante é desfrutar de todas as possibilidades de cada lugar, de cada parada, travando contato e experiências com os nativos da região; por isso o poeta se traveste num grande cosmopolita e sábio como foi o magno Ulisses. O receio do eu-lírico na última quadra é de cunho retórico, mas deixa evidente uma dúvida que só será respondida com o enfrentamento da aventura que se descortina, mesmo que isso signifique se encontrar com monstros, gigantes, ninfas dotadas de magia, sendo que estes seres podem remeter a este novo mundo, estas novas terras. É importante o intertexto firmado na epígrafe com o poeta alexandrino Konstantinos. Kaváfis (1863-1933) que em 1911 publicou um poema também nomeado "Ítacav", no qual Siewierski estabelece um diálogo profundo, inclusive respondendo à orientação feita por Kaváfis logo na primeira e terceira estrofes do referido texto:

Quando partires em viagem para Ítaca caminho,

faz votos para que seja longo o pleno de aventuras, pleno de conhecimentos.

Faz votos de que seja longo o caminho. 
estivais

Que numerosas sejam as manhãs alegria,

nas quais, com que prazer, com que

entrarás em portos vistos pela primeira vez;

pára em mercados fenícios

e adquire as belas mercadorias, nácares e corais, âmbares e ébanos

e perfumes voluptuosos de toda espécie,

e a maior quantidade possivel de voluptuosos perfumes;

vai a numerosas cidades egipcias, instruídos.

aprende, aprende sem cessar dos

Feitas as observações, passemos a apreciar o poema Canção do não-exílio, que não traz rebuscamento lexical, característica marcante da poética contemporânea, que prefere a simplicidade vocabular, sendo que a complexidade do texto reside em elementos de contrate $\mathrm{e}$ condensação de imagens, perspectivas, diegeses específicas versus figuração do real, paródia e diálogo com outros textos literários e metalinguagem:

\section{CANÇÃO DO NÃO-EXÍLIOvi}

Para o meu filho Michat, na viagem ao Paraguai, para pegar o visto brasileiro.

Este caminho dá pra Roma, já estamos em Mato Grosso; não jogue lixo pela janela este caminho é nosso.

Este caminho dá pro mar, seja qual for o destino; não jogue lixo pela janela este é o nosso caminho.

Este caminho dá pra noite, tem sinais luminosos; não jogue lixo pela janela este caminho é nosso.

Este caminho dá pra casa, não é caminho do exílio; 
não jogue lixo pela janela, este é o nosso caminho.

1987

No plano peirceano e em perspectiva de primeiridade este poema nos coloca ao lado do eu-lírico em pleno Brasil central, nos fornecendo uma imagem pouco clara deste país que o recebe. Á primeira vista, os signos somente se apresentam iconicamente, sendo quase-signos (Oliveira, 1999, p. 48), pois não há um desenho detalhado do lugar, não havendo representação da imagem, apenas sabemos que não é exílio: "Já estamos em Mato grosso". O pronome "Este" que inicia o poema e reaparece em todas as estrofes, é um dêitico exemplar da apresentação sígnica. Pensando o poema em termos de terceiridade sígnica, pode-se verticalizar de inúmeras maneiras a análise.

Primeiro pela imagem construída em "não jogue lixo pela janela", evidencia-se que a viagem é feita possivelmente de transporte terrestre. Cabe ainda salientar que os versos "Esse caminho dá pro mar" e "Esse caminho dá pra Roma" são uma espécie de "remotivação" de expressões ou palavras clichês, processo poético muito comum dentro das ambiguidades próprias da linguagem poética. Pode-se pensar inclusive nos seus correspondentes mais imediatos, encontrados em expressões populares sobejamente cristalizadas pelo uso: "Todos os caminhos levam a Roma" (dito popular) ou "todos os rios correm para o mar" (dito popular), considerando as variantes possiveis são falas comuns ao universo dos aventureiros, é uma espécie de alea jacta est utilizadas por desbravadores.

Em segundo lugar, é clara a intertextualidade com a Canção do Exílio de Gonçalves Dias, com poemas de Oswald de Andrade e com demais paródias existentes. Há aqui, entretanto, uma reorientação espacial e contextual da ideia, subvertendo a lógica gonçalviana, pois o eu-lírico aporta no Brasil sem ressentimentos, sem dúvidas insuperáveis, por livre e espontânea vontade. Não se trata de exílio, mas sim do não-exilio, de vinda motivada para uma nova terra acolhedora e simpática, e isso é importante se considerarmos a história recente do 
holocausto nazista que obrigou os poloneses - que não é o caso do eulírico deste poema - sobreviventes da Grande Guerra a um cisma, desenraizando-os, tornando-os apátridas e subservientes em diversos países do globo.

Ao contrário disso, o(as) viajante(s) farão parte de um novo Brasil pluriétnico e multifacetado, tropical e alegre. Nesse horizonte, não pode cantar como exilado nos termos de Gonçalves Dias, pois o eu-lírico está exatamente onde as "aves gorjeiam", onde os "bosques têm mais vida" e a "vida, mais amores".

O poeta adverte que "este é o nosso caminho" e "Este caminho dá pra casa”. A casa aparece como metáfora desse novo mundo. O verso "O caminho dá pra noite", simbolizando incertezas, mas também na noite há sinais luminosos que dizem o contrário, trazendo amparo e direcionamento. Novamente ressurge o aspecto da remotivação de expressões ou palavras clichês, mas agora com uma possibilidade adicional de vinculação a citações eruditas, sendo que aqui se tem um duplo movimento para o interior (sossego e segurança), a "casa": "A casa de um homem é o seu próprio castelo" (Coke, 1957, p. 118) e "noite" para o exterior (desafio, incerteza, aventura): "Noite - vala comum, sepultura do dia!" (Oscar Lopes, 1957, p. 357) e "A noite é uma criança” (dito popular).

No poema "O menino da praça", temos um retrato bem claro da realidade social brasiliense, excludente. A primeiridade deste poema está inscrita como subnivel da terceiridade metafórica, ou seja, as metáforas são rapidamente reconhecidas por leitores que conhecem a dura realidade "d'O menino da praça/ dos três poderes,/ filho não registrado/ dos dois candangos,/ de dia olha os carros/ e a bandeira,/ nas noites frias de junho/ seu corpo apátrida/ treme. (Brasilia, 1993)".

Não se pode, contudo, negligenciar o simbolismo, marca de terceiridade, presente nas estruturas "praça dos três poderes, carros, bandeira”. São elementos que nos direcionam à Brasília das decisões, do poder. É interessante notar que o fato de nascer no lugar não confere, à luz da orientação ideológica do poeta, status de cidadão. Isso 
se intensifica na medida em que se lembra da nacionalidade do poeta que é inicialmente polonês, mas é mais brasileiro que o menino desvalido, sem registro de nascimento e entregue às noites frias de junho. Além disso, e mais importante, é a evidenciação dos sentimentos de humanidade e solidariedade do poeta que contrasta o poder político ao resultado degenerado de suas ações: "o menino da praça”.

Seguindo sua promenade em solo brasileiro, o eu-lírico chega ao Marajó paraense. É mais um ápice de exaltação da nova morada, destacando suas tradições e belezas naturais: "popopó tucupi/ popopó tacacá/ (...) carimbo ó carimbo (...) a salvação vem do búfalo/ o leite da onça/ a política do açaí/ da argila/ imigrante nato. 2004". (poema "Marajó"). A terra de Marajó, este pedaço do Pará é uma ilha envolta no Rio Amazonas e no Oceano: "salgado-doce" sinestesia que se aplica também aos pratos típicos da região enaltecidos no poema: "tucupi e tacacá".

Gostaria de destacar a imagem do "imigrante nato", algo contraditório que só se resolve no plano metafórico onde alguém nasceu para viajar e viaja para renascer. Trata-se de alguém que está perpetuamente mudando, seja espacial ou psicologicamente Este poema é predominantemente de metáfora genotextual, ou seja, $2^{\circ}$ nível da metáfora.

A metáfora genotextual, denominada de $2^{\circ}$ grau, fundamenta-se essencialmente em imagens, isto é, em representações mentais. O elemento de ligação entre os termos baseia-se em analogias tiradas do mundo emocional do poeta. São metáforas sem motivações semânticas, de relações externas e subjetivas, que criam imagens novas, distantes e irracionais (Ângelus lilases). (OLIVEIRA, 1999, 131).

A mesma análise serve para o poema "Mãe d’água", no qual é essencial para a compreensão verticalizada do poema o conhecimento da mitologia indígena brasileira em paralelo à mitologia clássica europeia: há uma nítida correspondência entre a Iara ou Uiara com as Sereias gregas. A Mãe d'água tangencia essa relação na medida em que 
há uma similaridade conceitual com a Iara, apesar de aquela ser uma construção mítica genuinamente brasileira, diversamente da Iara que faz parte de um mundo mítico maior.

Através de um processo intenso de condensação poética, o que, aliás, é a tônica desta obra poética ora em análise, traz-se uma situação bastante peculiar do sentimento religioso do povo baiano: "Não é nossa senhora/ rainha do mar morena/ vive embaixo d'água,/ perto do Rio Vermelho".

Tal sentimento marcante é o sincretismo religioso, que o eulírico deste poema destaca do ponto de vista pagão em "rainha do mar morena", marcada pelo sol tropical, mas também evoca toda uma tradição cristã mais antiga condensada na imagem do Rio Vermelho. É de se reparar nas maiúsculas alegorizantes presentes. Este Rio Vermelho é um ponto de intersecção cultural, já que alude a universos religiosos diferentes; porém aproxima do ponto de vista das mitologias "Sereia-Iara-Mãe d'água-Nossa Senhora". Além disso, Rio Vermelho é um bairro de Salvador muito famoso pelo mito da mãe d'água.

Ao que parece, o "casamento" religioso feito na Bahia inspira o novo brasileiro, poeta viandante, a se integrar no novo mundo. Percebe-se que há espaço para uma convivência complementar em termos culturais, simbólicos e até místicos.

Provavelmente o próprio poeta está se familiarizando com este novo universo mitológico que, a despeito de semelhanças com as sereias e ninfas do mundo greco-latino, tem um tanto de tempero baiano, nordestino, nortista; é iemanjá, é Iara, é Uiara, o Brasil africano, o Brasil dos indigenas...

Em "Serra da Barriga" temos uma incursão no universo do Quilombo dos Palmares, terra que abrigou os negros "auto-alforriados" liderados por Zumbi. A expressão "A barriga da Serra", em contraposição à Serra da barriga, é uma metáfora do retorno ao âmago materno, ao aconchego, ao ambiente receptivo buscado por fugitivos ou talvez por novos aventureiros que não fogem necessariamente, mas fluem de outras esferas. As cinzas da Serra da Barriga talvez remetam 
ao massacre que dizimou os quilombolas ali refugiados. Porém há esperança de liberdade, pois, "Quando chegar a hora/ a luz do dia/ vai vestir de asas/ as cinzas peregrinas". O vocábulo "asas" confirma esta interpretação simbólica e a metáfora "cinzas peregrinas" indicia a destruição que não é completa, porque a diáspora segue seu curso; as cinzas são levadas pelo ar e repousam algures à espera da Fênix. É o que se observa seguindo a análise de Oliveira:

A metáfora é uma dupla representação: representa a representação de um representâmen. Imagem especular do próprio espelhamento: espelho que reflete refletido, qual Vênus, a um tempo metáfora da mulher e do amor, imagem refletida em espelho, por Velázquez, imagem da imagem. (OLIVEIRA, 1999, p. 125)

Neste poema, fica patente a construção peculiar de imagens que se amplificam em metáforas genotextuais da mais alta qualidade. As construções sintáticas deste poema são marcantes para amplificação de sentidos histórico, geográfico, estético e sociopolítico.

\section{O Brasil de Debret}

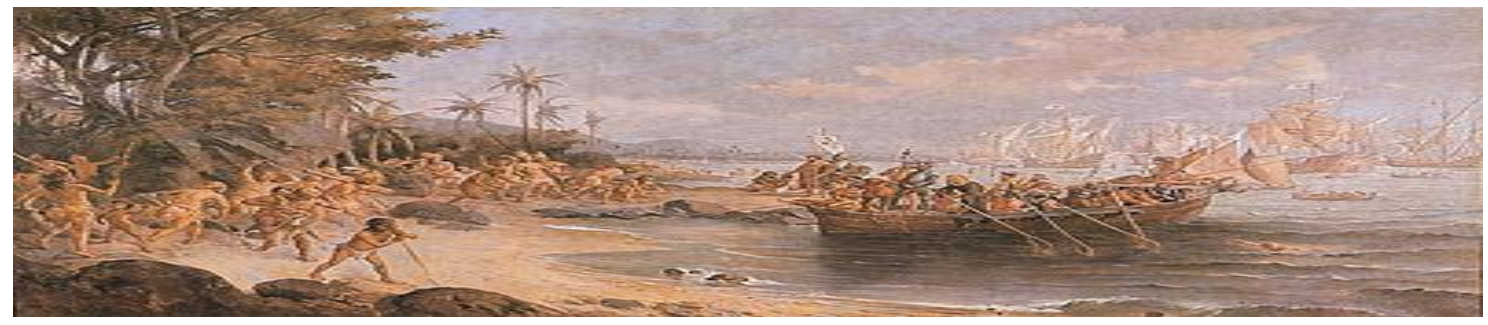

FIGURA 1 - Descoberta do Brasil (1922), Oscar Pereira da Silva. óleo sobre tela. 190 x 333 cm. Museu Paulista (São Paulo, SP) Fonte: ITAUCULTURAL, 2010

A imagem acima não é de Debret (é de Oscar Pereira da Silva), mas traduz o espírito do século XIX no Brasil que se descobre pela arte, pela pintura. Oito anos após a chegada da família real portuguesa sob o comando do monarca D. João VI, aporta em solo brasileiro a missão artística francesa, da qual se destacou a figura de Jean-Baptiste Debret. A referida "missão artística" foi incumbida de 
registrar artisticamente os atos e passos da recém-chegada realeza "luso-brasileira". Contudo, alguns pintores notáveis extrapolaram esta "dimensão oficial" e realmente produziram uma obra de envergadura muito mais pujante; Debret certamente se inscreve nesta perspectiva. Assim, o que a pintura debretiana nos oferece é menos um quadro fiel da realidade brasileira do século XIX, qual seja, um Brasil escravista, latifundiário, segregador e atrasado, sendo mais uma interpretação estética e pictórica com o olhar sensivel de um perspicaz observador estrangeiro que buscou retratar a nova corte portuguesa e o povo nos ângulos cultural, religioso e de costumes, superando os pontos exclusivamente políticos do incipiente império.

As pinturas de Debret aqui em análise têm como foco central a questão representacional do negro, da escravidão, ou mais propriamente a leitura que este pintor estabeleceu com um novo mundo completamente diferente da Europa de então, nos fazendo ver e principalmente pensar o Brasil oitocentista dentro das contradições inerentes a um país de categoria periférica.

Pensando a arte pictórica de um modo lato e também a arte de Debret, segundo Oliveira (1999), pode-se alinhavar certa equivalência entre a representação na pintura e na literatura (poesia): "o caráter representativo do visual tangencia o caráter representativo da metáfora" (Oliveira, 1999, p. 129). E, além disso, citando Santaella, o mesmo autor pondera que o "visual representa, por força de imagem simbólica, através de três dimensões: analogia/semelhança, figuração/cifra e convenção/sistema" (ibidem, p. 129), com correspondência nos três níveis da metáfora: fenotextual, genotextual e alegoria.

Aprofundando o magistério de Oliveira (1999), tem-se que a analogia é quando há uma relação, embora convencional, entre signo e objeto, e persiste uma relação analógica perceptível: já na figuração há um maior hermetismo, desaparecendo a analogia, e na convenção não há relação de similaridade, onde o que importa é a relação com o sistema que o preside, significando em função dele. A partir daqui o que nos interessa é estabelecer dentro dos quadros de Debret selecionados 
como se dão estas relações metafóricas que trazem em si a tríade primeiridade-secundidade-terceiridade.

Debret, o mais conhecido dos integrantes da Missão artística francesa de 1816 foi um arguto desenhista do mundo brasileiro do século XIX. Em sua aquarela sobre papel Casario (figura 2) percebe-se a presença marcante do nível analógico, típico da pintura histórica, que pretende apreender historicamente o real. O Casario representado é facilmente reconhecível como arquitetura do século XIX. A condição dos escravos é representada analogicamente no mesmo sentido, carregando seus "senhores" ou jarros d'água. Como o foco é no casario, os escravos surgem com formas e feições pouco claras. Inclusive as cores das roupas e demais traços são progressivamente "apagados", dando uma ideia do papel "marginal" que ocupam naquela sociedade, instaurando-se inclusive uma contradição, pois os escravos representados no quadro eram os legitimos produtores da economia brasileira.

$\mathrm{Na}$ figura 3, Debret dá coloração mais nítida à situação dos escravos em pleno "serviço". Há um plano analógico claro, contudo não se permanece apenas nesse patamar metafórico; percebe-se, pelo tipo de trabalho empreendido, que se trata da manufatura da cana-deaçúcar, produto primário essencial do Brasil colônia e império e, por força de uma análise metafórica convencional e pela própria leitura da História do Brasil do referido período, infere-se que o trabalho escravo foi fulcral para a realização da economia brasileira, fato que não passou despercebido pelo pincel debretiano. A nitidez da feição do escravo que está de pé à esquerda sugere isso também.

$\mathrm{Na}$ figura 4 temos uma amplificação do caráter convencional da metáfora, pois há necessidade de se conhecer previamente o contexto histórico-cultural para melhor interpretação do quadro, evidenciando uma necessidade de um estudo semiótico mais específico e pormenorizado. Artista de formação neoclássica, Debret trava contato com um Brasil bem diferente da França. O escravismo é uma constante em sua obra e de algum modo ele tentou conciliar estes 
dois mundos por meio de uma transfiguração da mitologia grega. A fusão das realidades brasileira europeia fica patente no nome dado ao músico posto em relevo no centro do quadro: "o velho Orfeu africano".

Orfeu, poeta e músico da mitologia grega, ressurge africanizado em processo sincrético correlato ao descrito acima neste trabalho sobre a Sereia e a Iara. Aliás, Orfeu ficou famoso por acalmar as Sereias com sua lira a serviço de Jasão e seus “argonautas”. Além disso, é célebre o caso de amor de Orfeu e Eurídice, em que esta foi morta e recebeu autorização de Hades para regressar ao mundo dos vivos desde que Orfeu não a olhasse até o surgimento da luz.

Nota-se que a alegria de Orfeu pouco a pouco se converteu em tristeza profunda, já que ele não foi capaz de cumprir as regras de Hades, fazendo com que Eurídice retornasse ao mundo dos mortos. Debret substitui a lira grega pelo berimbau tupiniquim ou pelo seu possivel ancestral, o "Oricongo", sendo que o Orfeu africano desempenha igual papel no contexto do quadro (figura 4), pois está a serviço de alegrar a massa de escravos, calejada do trabalho; participa deste modo da alegria da companhia com iguais (mundo de luz), ao mesmo tempo em que convive com a quase certeza do açoite diário (mundo das sombras).

$\mathrm{Na}$ figura 5, o escravismo, tema central em Debret, chega ao universo religioso. O sincretismo religioso se faz presente, inclusive na nova figuração dos representantes da igreja e do batismo dos pequenos escravos, que não tinham escolha possivel no plano religioso a não ser a adesão aos dogmas da Igreja. Diante de tal perspectiva, restava-lhes uma reorientação de seus mitos e crenças dentro dos cânones católicos, inclusive do ponto de vista da vestimenta mínima para poder frequentar a "casa de Deus". Pode-se concluir, por meio de análise metafórica convencional que o escravo em reverência a autoridade eclesiástica representa a submissão do negro africano, relegando suas tradições religiosas por imposição senhorial. Ao mesmo tempo pode representar uma integração incipiente ao mundo da cultura dominante, tese talvez difícil de sustentar-se, dado o hermetismo da figuração. 


\section{Conclusão}

O trabalho indicou que a teoria fundada por Oliveira (1999) em seu estudo quanto à equivalência e possibilidade de análise da pintura e da poesia sob o viés da metáfora em seus três níveis se mostra bastante adequado e proficuo. O que vai merecer ainda muita discussão dentro dos estudos da semiótica, especialmente a peirceana. Os poemas de Siewierski e os quadros analisados de Debret denotam, em diferentes contextos históricos, a riqueza do olhar do outro, da alteridade. Estes artistas demonstraram por meio da especificidade de suas expressões artísticas uma possibilidade de contato entre culturas sem o viés de cima para baixo, típico do colonizador português do século XIX ou do pensamento eurocêntrico, via dominação simbólica por meio das artes e tecnologias, vigente ainda que de forma mais pulverizada e desconcentrada até os dias atuais.

Não quero dizer com isto que os trabalhos são imunes a ideologias; a natureza essencial dos poemas e quadros analisados é primeiramente estética, mas não se pode negar que o fato estético é profundamente marcado pelas ideologias da época - levando-se em consideração como o artista as processa e as difunde -, sendo que não há arte ingênua: em todos os momentos decisivos da história social e política a arte estava em relevo ou se direcionava para esta condição.

O conteúdo e forma artísticos são construções ou leituras de mundo. Por isso, estão carregados de sentidos múltiplos e que podem ser muitas vezes contraditórios entre si. No caso de Debret, há que se perceber o papel que o colonialismo europeu e escravismo brasileiro desempenharam em sua expressão artística. A estética que pinta os quadros é oriunda da formação erudita e europeia de Debret, contudo, esta se funde com o olhar sincrético e marcado de ideologia do pintor, pois ele não se tratava de um mero empregado da Corte Portuguesa: era um grande artista que "subverteu" a realidade do seu modo. A perspectiva analítica depende de onde vem olhar e para onde ele vai. O 
trabalho artístico de Debret funda-se numa representação realista da realidade, que é sem dúvida ideológica, porém, mesmo assim, marca sua visão de mundo de modo cabal. Lukács (1974, p. 11-12) já propunha uma estética baseada em elementos do cotidiano e, para ele, o realismo era perfeito dentro tal propósito. A obra debretiana lança luz nas contradições do Brasil escravista e ao mesmo tempo pomposo do século XIX.

Em ralação ao poeta Siewierski, como cidadão polonês de nascimento, pode-se aventar que a ascensão e a queda do socialismo em seu país parece tê-lo tocado, o que se evidencia pelos poemas de cunho socializante como "Menino da Praça", onde fica patente a preocupação social do escritor. Outra marca dos poemas analisados se refere busca de novos horizontes e lugares: o exílio, a viagem, a imigração são constantes que traduzem a natureza diaspórica do poeta, instaurando uma ideologia em sua estética que poderíamos chamar de cosmopolitismo poético contemporâneo.

O fato concreto é que as ideologias influenciam estéticas e viceversa. Inscrevo estes termos no plural para marcar as delicadas e/ou abruptas diferenças de significado que ambas sofreram e sofrem no percurso histórico. Nos brilhantes livros A ideologia da estética e La estética como ideologia (referência completa na bibliografia) sobre esta relação, Terry Eagleton, nos traz logo nos títulos a problemática complexa entre ideologia e estética em sua bidirecionalidade. No fim, portanto, o quadro sociopolítico influencia e é influenciado pela arte. Os elementos teóricos da semiótica peirceana provavelmente não darão conta de explicitar esta complexidade de maneira isolada; porém, não há dúvidas que o legado de Peirce no campo da lógica nos proporciona equipamento teórico suficiente para iniciar esta jornada, juntamente com as ricas propostas de Terry Eagleton e György Lukács em relação à estética e à ideologia

\section{QUADROS DE DEBRET CITADOS}


Figura 2

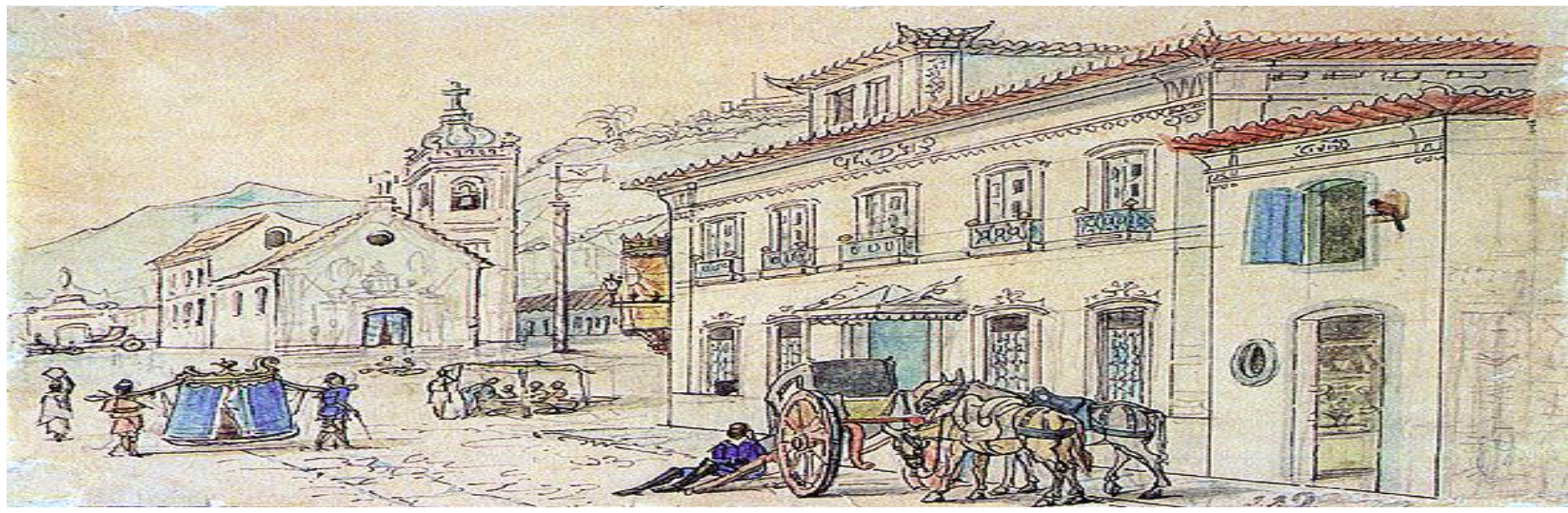

Debret. Casario 1816 - 1831 aquarela sobre papel, c.i.d. 12,4 x 20,1 cm Museus Castro Maya - IPHAN/MinC (Rio de Janeiro, RJ) Fonte: ITAUCULTURAL, 2010

Figura 3

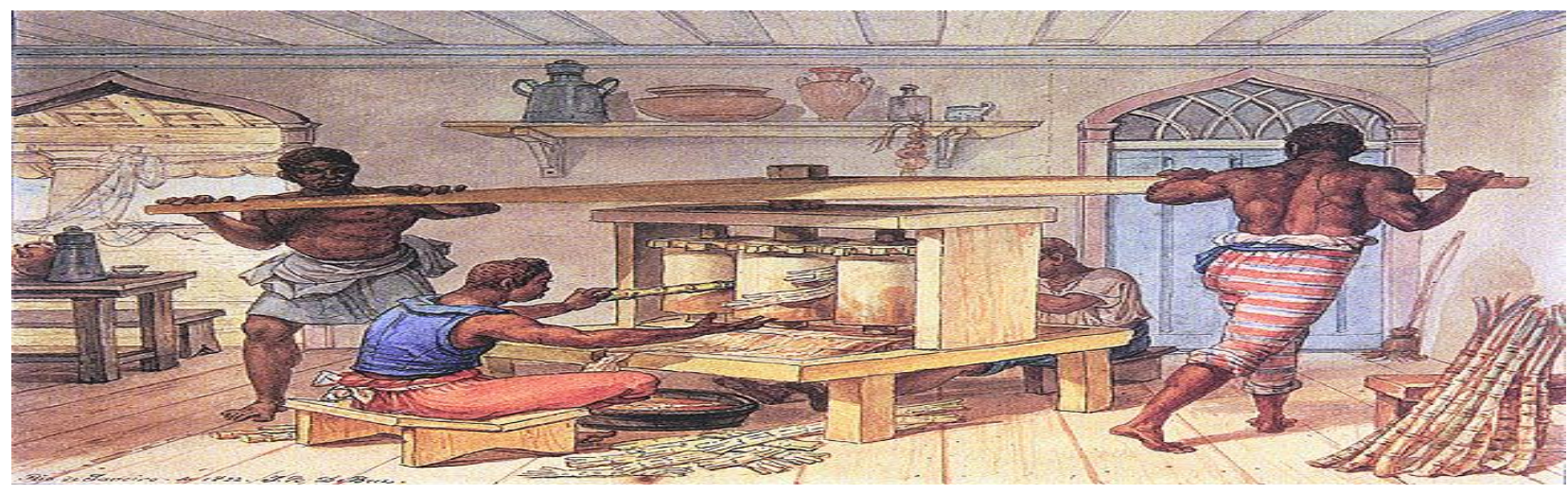

Debret. Engenho Manual que Faz Caldo de Cana, 1822 aquarela

sobre papel, c.i.e.

17,6

$\mathrm{x}$

24,5

$\mathrm{cm}$

Museus Castro Maya - IPHAN/MinC (Rio de Janeiro, RJ) Reprodução fotográfica Pedro Oswaldo Cruz Fonte: ITAUCULTURAL, 2010

Figura 4

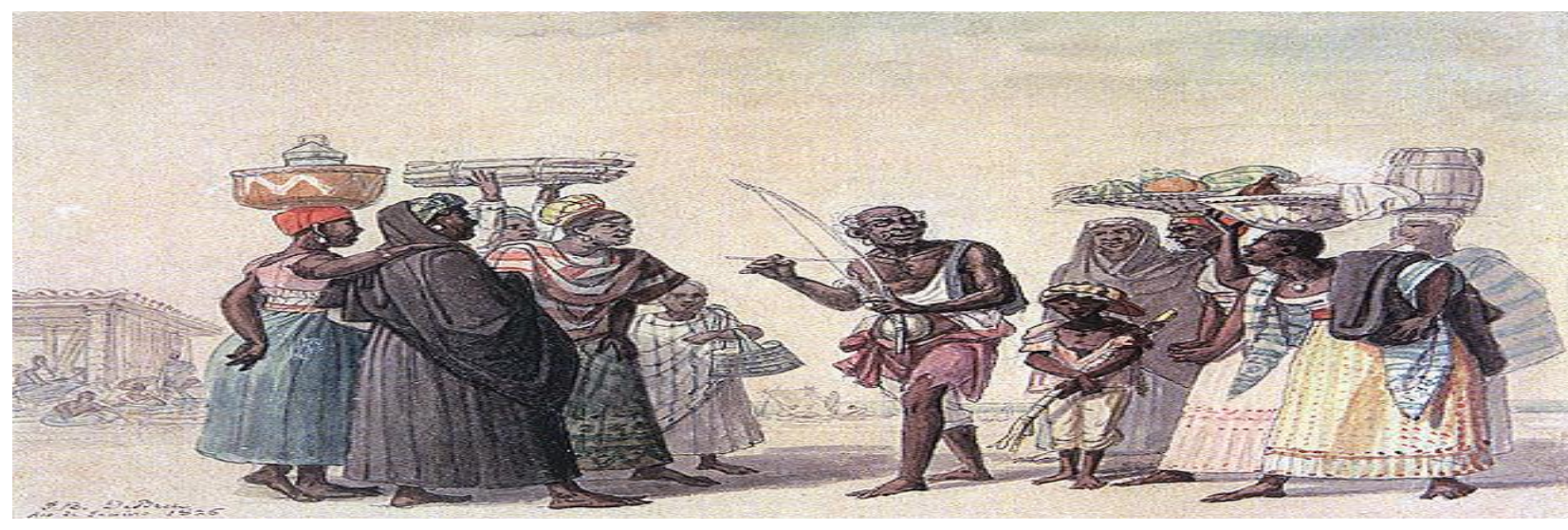


Debret. O Velho Orfeu Africano. Oricongo, 1826 aquarela sobre papel, c.i.e. 15,6 x 21,5 cm Museus Castro Maya - IPHAN/MinC (Rio de Janeiro, RJ) Reprodução fotográfica Pedro Oswaldo Cruz Fonte: ITAUCULTURAL, 2010

Figura 5

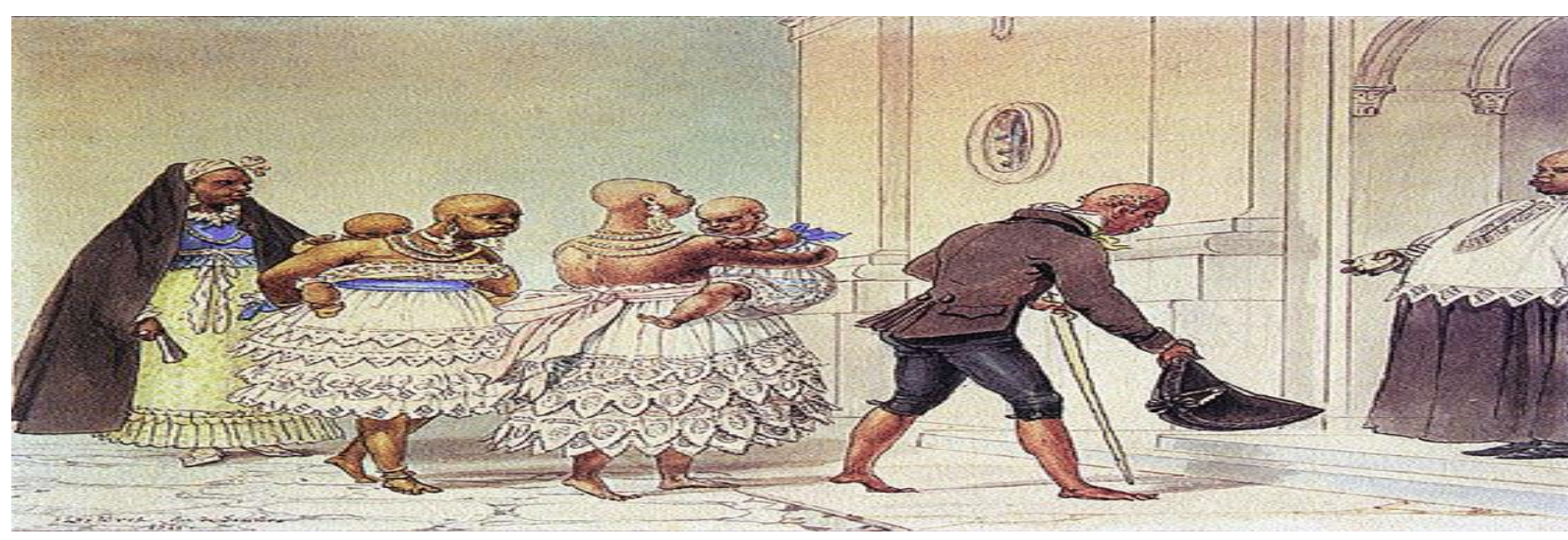

Debret. Jovens Negras Indo à Igreja para Serem Batizadas,

1821 aquarela sobre papel, c.i.e.18,3 x 23,5 cm Museus Castro Maya - IPHAN/MinC (Rio de Janeiro, RJ) Reprodução fotográfica Pedro Oswaldo Cruz Fonte: ITAUCULTURAL, 2010.

\section{Notas}

i "Primeiridade é a categoria que dá à experiência sua qualidade distintiva, seu frescor, originalidade irrepetivel e liberdade. Não a liberdade em relação a uma determinação física, pois que isso seria uma proposição metafísica, mas liberdade em relação a qualquer elemento segundo. O azul de um certo céu, sem o céu, a mera e simples qualidade do azul, que poderia também estar nos seus olhos, só o azul, é aquilo que é tal qual é, independente de qualquer outra coisa. Mas, ao mesmo tempo, primeiridade é um componente do segundo. Secundidade é aquilo que dá à experiência seu caráter factual, de luta e confronto. Ação e reação ainda em nível de binariedade pura, sem o governo da camada mediadora da intencionalidade, razão 
ou lei. Finalmente, terceiridade, que aproxima um primeiro e um segundo numa sintese intelectual, corresponde à camada de inteligibilidade, ou pensamento em signos, através da qual representamos e interpretamos o mundo. Por exemplo: o azul, simples e positivo azul, é um primeiro. O céu, como lugar e tempo, aqui e agora, onde se encarna o azul, é um segundo. A síntese intelectual, elaboração cognitiva - o azul no céu, ou o azul do céu -, é um terceiro." (Cf. SANTAELlA, Lúcia. o que é Semiótica. São Paulo: Brasiliense, 1984. [Primeiros Passos].

ii É interessante destacar que o surgimento das vanguardas europeias, tais como futurismo, dadaísmo, surrealismo, fovismo, etc estabeleceu modelos estéticos tanto na literatura quanto nas artes plásticas.

iii $\quad$ SIEWIERSKI, Henryk. Outra Língua. São Paulo: Ateliê Editorial. 2007, p. 13.

iv A pergunta do Artigo "Ítaca: ponto de chegada ou ponto de partida?", de Rita de Cassi nos parece bastante instigante, pois as imagens de Ítaca, terra de Ulisses, são uma espécie de lugar ideal, um Eldorado reatualizado pela lírica contemporânea de Outra língua. Cf. SANTOS. Rita de Cassi. Ítaca: ponto de chegada ou ponto de partida? Artigo disponivel em http://unb.revistaintercambio.net.br/24h/pessoa/temp/anexo/1/271/227.pd $\underline{\mathrm{f}}$, acessado em 02/03/2011.

v Disponivel em http://org2.blogspot.com/2007/03/tido-comoum-dos-mais-importantes.html, acessado em 04/03/2011.

vi SIEWIERSKI, Henryk. Outra Lingua. São Paulo: Ateliê Editorial. 2007, p. $20-21$.

\section{REFERÊNCIAS BIBLIOGRÁFICAS}

ANDRADE. Carlos Drummond de. Estive em casa de Candinho. In: Confissões de Minas. In: Poesia e prosa: volume único. $8^{\mathrm{a}}$ ed. Rio de Janeiro: Nova Aguilar, 1992. p. 1354-1356. (Biblioteca luso-brasileira. Série brasileira). 
APOLINNAIRE. Guillaume. Caligramas. Tradução de Álvaro Faleiros. Edunb. Brasília \& Ateliê Editorial, 2008.

ARISTÓTELES, Arte retórica e arte poética. São Paulo: Difusão Européia do Livro, 1959.

BALZAC, Honoré de. Comédia Humana. Porto Alegre, Globo, 1954. Org. de Paulo Rónai e trad. de Gomes da Silveira e Vidal de Oliveira [Vol. XV, (Estudos Filosóficos), “A Pele de onagro" ("Peau de chagrin”) e "Obraprima ignorada" (“Chef-d'oeuvre inconnu”)].

BARICCO. Alessandro. Oceano Mar. São Paulo, Iluminuras, 1996.

BAUDElAIRE, Charles. Obra Completa. Tradução de Alexei Bueno et alii. Rio de Janeiro: Nova Aguilar, 1995.

BOSI, Alfredo. O ser e o tempo na poesia. São Paulo: Companhia das Letras, 2000.

DEBRET, Jean Baptiste. Viagem pitoresca e histórica ao Brasil. Belo Horizonte, Itatiaia; São Paulo, Edusp, 1989.

EAGLETON, Terry. Ideologia: uma introdução. Tradução de Silvana Vieira e Luís Carlos Borges. São Paulo: Editora UNESP: Editora Boitempo, 1997.

A Ideologia da Estética. Jorge Zahar Editor, 1990.

- La estetica como ideologia. Ed. Trotta, 2006. Traducción de German Cano y Jorge Cano. Edicion original, T.Eagleton, 1990 en Blackwell Prublishing Ld., Oxford. 
GOMES, Laurentino. 1808: Como uma rainha louca, um príncipe medroso e uma corte corrupta enganaram Napoleão e mudaram a História de Portugal e do Brasil. São Paulo: Ed. Planeta, 2008.

KAVÁFIS. K. Poemas de K. Kaváfis. - Tradução, estudo e notas de Îsis Borges da Fonseca. São Paulo: Odysseus Editora, 2006.

LUKÁCS, György. Estética, v. I, Barcelona, Ed. Grijalbo,1974.

MENDES. Murilo. Poesia Completa e prosa. Rio de Janeiro, Nova Aguilar, 2006.

OLIVEIRA, Valdivino Soares de. Poesia e Pintura: um diálogo em três dimensões. São Paulo: Ed. UNESP, 1999.

PAMUK, Orhan. Meu nome é vermelho. São Paulo, Cia das Letras, 2004.

REIS, Abel, Aproximações ao conceito de metáfora em C. S. Peirce. Cadernos de Semiótica Aplicada (CASA)Vol. 4. n.2, dezembro de 2006.

RICOEUR, Paul. A metáfora viva. Trad. Dion Davi Macedo. São Paulo: Loyola, 2000.

SANTAELlA, Lúcia. O que é Semiótica. São Paulo: Brasiliense, 1984. [Primeiros Passos].

SANTOS. Rita de Cassi. Ítaca: ponto de chegada ou ponto de partida? Artigo disponivel em http://unb.revistaintercambio.net.br/24h/pessoa/temp/anexo/1/271/ 227.pdf, acessado em 02/03/2011. 
SIEWIERSKI, Henryk. Outra Lingua. São Paulo: Ateliê Editorial. 2007.

TELES. Gilberto Mendonça. Vanguarda européia e modernismo brasileiro, Petrópolis, vozes, 1987.

WILDE, Oscar. O retrato de Dorian Gray. Trad. Maria Cristina F. da Silva. São Paulo: Nova Cultural, 1996.

MASUCCI. Folco. Dicionário de Pensamentos, máximas, aforismos, paradoxos, provérbios, etc. de autores clássicos e modernos, nacionais e estrangeiros. São Paulo, 1957. 